\title{
30 回目を迎えた本格焼酎鑑評会
}

独立行政法人酒類総合研究所が毎年 1 回開催している本格焼酎鑑評会も, 回を重ねて 30 回目となった。 第 1 回は昭和 52 年（1977 年）というから, 当時はまだまだ南九州を中心とするローカルな酒であったが, 今や全国どこでも嗜むことができる人気の高い，洗練された酒になった。この間にあって，高品質を維持す るための醸造技術を問いかけ，谷の進歩を見続けて来たのがこの鑑評会である。

本稿から本格焼酎, いわゆる単式蒸留しょうちゅうの現在の姿を汲み取っていただきたい。

向井伸彦

\section{1. はじめに}

本格焼酎鑑評会は，単式蒸留しょうちゅうの品質を 全国的な視野でとらえ，現在の製造技術の内容と酒質 の傾向を把握するとともに製造業者の参考とすること を目的に開催されています。第 1 回目は昭和 52 年 （1977 年）に開催されました。途中研究所の東広島市 への移転による開催の中止（平成 7 年）以外は毎年開 催されており, 今年で第 30 回目を迎えました。

本格焼酎鑑評会では，専門家による官能評価及び化 学成分分析によって出品酒の品質を評価しています。 さらに, 個々の品質評価結果を出品製造場へ通知して います。本格焼酎鑑評会開催のメリットとして, 主催 者側にとっては, 全国規模で単式蒸留しょうちゅうの 酒質の動向を把握することができる他, 官能評価や化 学成分分析值を知ることによって単式蒸留しょうちゅ うの品質向上のための調查研究資料にすることなどが 挙げられます。一方, 出品者側にとっては, 自社市販 製品の製造技術面も含めた品質の客観的な把握や, 公 開きき酒会における全国的な酒質の動向が把握できる ことなどが挙げられます。

このようにして, 本格焼酎鑑評会を通じて単式蒸留 しょうちゅうの製造技術や品質の向上が図られてきま した。な扔, 鑑評会と品評会の相違については, 中 野1)の解説がありますが, 本格焼酎鑑評会では, 褒賞 授与は行われていません。

国税庁の「酒のしおり」によると，この間（1977 年から 2005 年までの 28 年間) の酒類全体の製成数量
は 1.4 倍程度増加しましたが, 近年は横ばいか減少傾 向にあります。一方, 単式蒸留しょうちゅうの製成数 量は 5.8 倍に増加しています(第 1 図)。単式蒸留し ょうちゅうの消費は, かつては九州・沖縄地方が中心 でしたが, 現在では広く全国的に消費され, 身近な酒 類の 1 つなっています。

以下に, 最近の本格焼酎鑑評会の開催状況を中心に 述べます。なお，これまでの本格焼酎鑑評会について

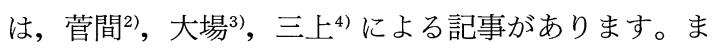
た, 各回の出品状況, 審查方法, 成分分析結果等につ いては, 酒類総合研究所報告 (醸造研究所報告, 醸造 試験所報告）（第 149 号 $(1977)^{5)}$ 以降）に記載されて います。これらについてもあわせてご参照ください。

\section{2. 出品点数について}

原料別の出品点数の推移を第 2 図に示しました。 1980 年代中頃単式蒸留しょうちゅうの製成数量が大 幅に伸びるとともに出品点数も顕著に増加し, 第 10 回（1986 年）において 427 点とピークとなりました。 その後, 出品点数は暫く 250 点前後で推移してきまし たが，ここ数年は再び増加傾向にあり，今回（第 30 回）の出品点数は前回から 10 点増加の 347 点となり ました。

東広島への移転後の第 19 回以降の都道府県別の出 品点数及び出品場数の推移を第 1 表及び第 2 表に示し ました。本格焼酎・泡盛の主産地である九州・沖縄地 方はもとより，全国から幅広く出品されています。第 26 回以降は, 出品場数についても増加しており, 出

Analysis of Traditional Shochu Presented to the Contest during Thirty Years Nobuhiko MukaI (National Research Institute of Brewing) 
(A) しょうちゅう



年度

(B) 酒類合計

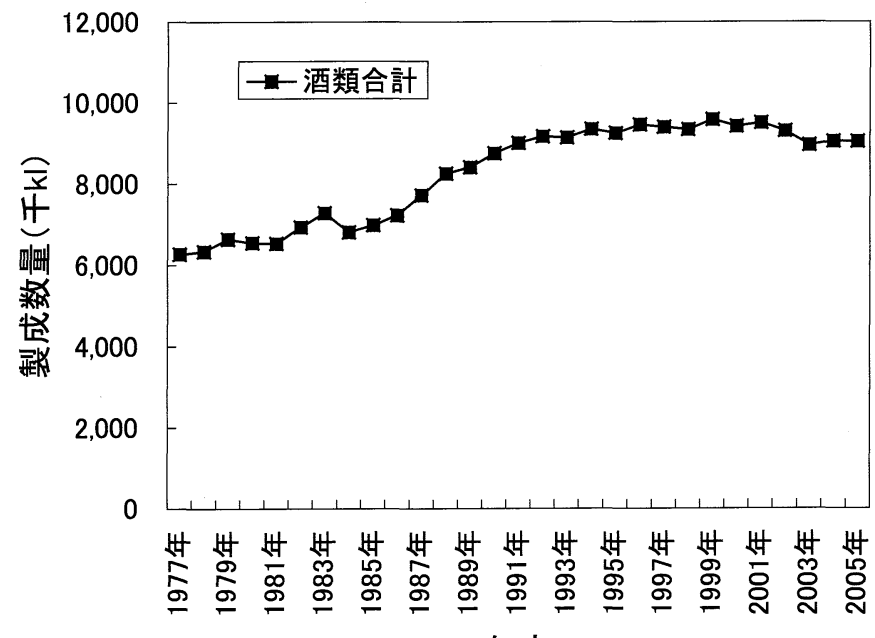

年度

第 1 図 酒類製成数量の推移

品者の関心が最近ますます高まっていることがうかが われます。

第 24 回までは 1 製造場につき原料別に各 1 点及び 特殊製品 (長期貯蔵酒等) 1 点という出品点数の制限 がありましたが, 第 25 回より出品点数の制限が廃止 されました。このことにより, 同一原料で製法の異な る 2 種類以上の製品を出品し, 客観的に品質を比較す ることが可能となりました。なお, 独立行政法人化後
の第 25 回より，受益者負担の観点から出品が有料化 されています。

ところで, 最近の特徵として甘藷焼酎の出品の大幅 な増加が挙げられます。甘藷焼酎の出品は, 前回（第 29 回）において 79 点の出品があり, 過去最高の出品 点数となりましたが, 今回（第 30 回）は，前回をさ らに 9 点上回る 88 点の出品があり, 過去最高を更新 しました。甘藷焼酎の出品の増加の要因については, 


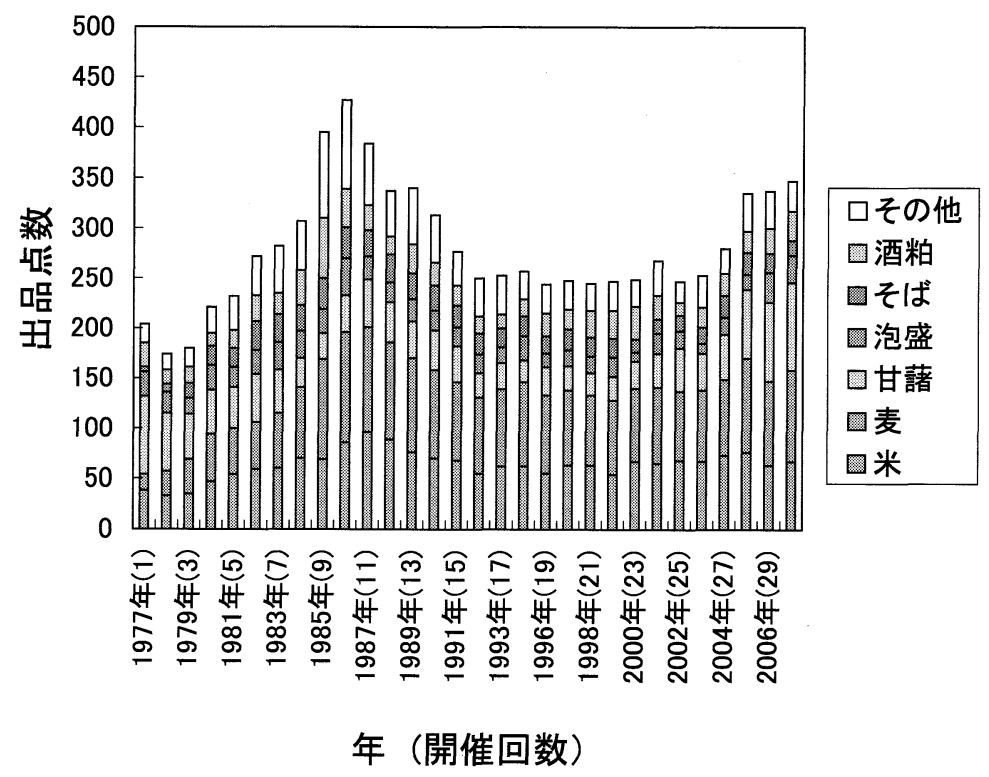

第 2 図 出品点数の推移

後ほど考察します。

本格焼酎鑑評会に出品された, 主要原料（米，麦， 甘藷, 泡盛, そば, 酒粕, 白糠, 黒糖) 以外の各種原 料の内訳を第 3 表に示しました。現在までに非常に多 くの原料を利用した焼酎が出品されていますが，最近 でも初めて出品されるものがあります。例えば，第 26 回ではヤーコン，ヤマトイモ及びくわいが，第 27 回では牛乳が, 第 28 回では梅の種, 菊芋, しそ及び レタスが，第 29 回では，生姜及びもち麦が，第 30 回 ではわさびが，それぞれ原料として初めて出品されま した。

さらに，原料の多様化の例として，通常泡盛の製造 では夕イ産米が使用されますが，地元沖縄県産米を使 用した泡盛が今回初めて出品されました。

\section{3. 官能評価について}

官能評価の方法は，製造上の問題点あるいは香味の 特徴などを明らかにすることを目的とする分析型と， 好き嫌いに基づいて判断する嗜好型とに大きく分ける ことができます。本格焼酎鑑評会は，分析型の官能評 価を行っており, 第 10 回以降第 3 図に示すマークシ 一トを用いたプロファイル法で行っています。出品酒 を使用原料毎に減圧蒸留製品, 常圧蒸留製品及び特殊 製品（長期貯蔵酒，樽貯蔵酒及び特殊な製造方法によ
る製品）の 3 区分に分け，香り，味，原料特性及び総 合評価の 4 項目について 5 段階評価を行っています。 また，香り・味については，特性（長所）について 11 項目, 指摘項目について 20 項目のチェックを行っ ています。すべての工程が凝縮されているのが最終製 品であり, 官能評価により製品の香味の特徴を明らか にできる他, 各製造工程の巧拙も把握できます。機器 を用いた化学分析の測定技術は日久進歩しています が，ヒトによる官能評価は，品質を瞬時にトータルで 評価できる点で優れています。

なお，官能評価には市販酒のアルコール度数及び $20 \%$ に割水した焼酎を用いています。

審査員は，酒類総合研究所理事長が選任した学識経 験者，製造・販売関係者，公設酒造指導機関，国税局 の技官及び当研究所職員で構成されています。第 30 回では，32 名の審査員が 2 組に分かれ，A 班が麦, そば，酒粕及びその他の焼酎を，B 班が米，泡盛及び 甘藷焼酎の審査を行いました。

\section{4. 成分分析について}

第 30 回では，発酵管理，蒸留操作及び貯蔵管理の 巧拙や, 品質の把握のための指標となる化学成分とし て, $\mathrm{pH}$, 酸度, 紫外部吸収, チオバルビツール酸価 (TBA 価)，ガスクロマトグラフィー $(\mathrm{GC})$ を用い 
第 1 表 都道府県別出品点数の推移

\begin{tabular}{|c|c|c|c|c|c|c|c|c|c|c|c|c|c|}
\hline \multirow{3}{*}{ 国税局名 } & \multicolumn{13}{|c|}{ 出品点数 } \\
\hline & 開催回数 & 19 & 20 & 21 & 22 & 23 & 24 & 25 & 26 & 27 & 28 & 29 & 30 \\
\hline & 開催年 & 1996 & 1997 & 1998 & 1999 & 2000 & 2001 & 2002 & 2003 & 2004 & 2005 & 2006 & 2007 \\
\hline 私璂 & 北海道 & 7 & 8 & 8 & 7 & 8 & 6 & 2 & 2 & 1 & $\overline{4}$ & $\overline{4}$ & 2 \\
\hline \multirow{6}{*}{ 仙台 } & 青森 & 0 & 1 & 1 & 1 & 1 & 1 & 0 & 0 & 0 & 0 & 0 & 2 \\
\hline & 岩手 & 0 & 0 & 1 & 6 & 4 & 4 & 2 & 2 & 0 & 0 & 0 & 3 \\
\hline & 宮城 & 0 & 0 & 0 & 0 & 0 & 0 & 0 & 0 & 0 & 0 & 0 & 1 \\
\hline & 秋田 & 5 & 3 & 3 & 3 & 4 & 4 & 2 & 4 & 5 & 5 & 3 & 6 \\
\hline & 山形 & 2 & 0 & 0 & 0 & 0 & 0 & 0 & 0 & 4 & 3 & 1 & 7 \\
\hline & 福島 & 2 & 4 & 2 & 2 & 6 & 6 & 2 & 0 & 2 & 0 & 2 & 6 \\
\hline \multirow{6}{*}{ 関東信越 } & 茨城 & 0 & 0 & 0 & 1 & 0 & 0 & 0 & 1 & 1 & 4 & 4 & 3 \\
\hline & 杤木 & 1 & 1 & 2 & 0 & 1 & 1 & 0 & 0 & 0 & 1 & 2 & 2 \\
\hline & 群馬 & 0 & 0 & 0 & 1 & 1 & 4 & 0 & 0 & 0 & 2 & 0 & 1 \\
\hline & 新潟 & 0 & 0 & 2 & 2 & 2 & 3 & 2 & 1 & 1 & 5 & 3 & 7 \\
\hline & 埼玉 & 0 & 0 & 0 & 1 & 2 & 0 & 0 & 0 & 0 & 3 & 0 & 0 \\
\hline & 長野 & 15 & 18 & 15 & 17 & 16 & 19 & 16 & 23 & 22 & 22 & 19 & 13 \\
\hline \multirow{4}{*}{ 東京 } & 千葉 & 6 & 3 & 2 & 2 & 2 & 3 & 2 & 4 & 5 & 6 & 4 & 6 \\
\hline & 山梨 & 1 & 0 & 2 & 2 & 2 & 2 & 4 & 3 & 4 & 0 & 0 & 0 \\
\hline & 東京 & 3 & 4 & 4 & 4 & 2 & 3 & 0 & 0 & 3 & 2 & 0 & 1 \\
\hline & 神奈川 & 1 & 0 & 1 & 2 & 0 & 0 & 0 & 0 & 2 & 0 & 0 & 0 \\
\hline \multirow{3}{*}{ 金沢 } & 石川 & 0 & 0 & 0 & 0 & 0 & 0 & 1 & 0 & 0 & 0 & 0 & 0 \\
\hline & 富山 & 1 & 1 & 1 & 1 & 1 & 1 & 0 & 0 & 0 & 1 & 1 & 0 \\
\hline & 福井 & 1 & 3 & 2 & 1 & 2 & 2 & 2 & 0 & 0 & 0 & 3 & 0 \\
\hline \multirow{4}{*}{ 名古屋 } & 岐阜 & 3 & 1 & 3 & $\overline{1}$ & 1 & 1 & 1 & 3 & 3 & $\overline{2}$ & 0 & 0 \\
\hline & 静岡 & 0 & 2 & 1 & 0 & 2 & 1 & 1 & 0 & 1 & 3 & 4 & 6 \\
\hline & 愛知 & 0 & 3 & 2 & 0 & 0 & 1 & 0 & 0 & 1 & 0 & 1 & 1 \\
\hline & 重 & 0 & 0 & 0 & 0 & 0 & 0 & 0 & 0 & 0 & 0 & 2 & 4 \\
\hline \multirow{6}{*}{ 大阪 } & 滋賀 & 1 & 3 & 5 & 4 & 3 & 3 & 0 & 1 & 1 & 0 & 2 & 0 \\
\hline & 京都 & 2 & 3 & 3 & 5 & 7 & 8 & 9 & 9 & 6 & 10 & 10 & 10 \\
\hline & 大阪 & 0 & 0 & 0 & 0 & 0 & 0 & 0 & 2 & 9 & 8 & 11 & 6 \\
\hline & 兵庫 & 4 & 5 & 6 & 6 & 4 & 1 & 3 & 4 & 7 & 5 & 5 & 6 \\
\hline & 奈良 & 3 & 3 & 4 & 4 & 5 & 3 & 1 & 2 & 0 & 0 & 1 & 1 \\
\hline & 和歌山 & 0 & 1 & 1 & 1 & 1 & 2 & 0 & 0 & 0 & 1 & 1 & 3 \\
\hline \multirow{5}{*}{ 広島 } & 鳥取 & 0 & 1 & 0 & 0 & $\overline{1}$ & 0 & 1 & 1 & 3 & 3 & 6 & 3 \\
\hline & 島根 & 2 & 0 & 0 & 0 & 0 & 0 & 0 & 1 & 2 & 0 & 4 & 3 \\
\hline & 岡山 & 1 & 3 & 2 & 1 & 6 & 4 & 5 & 5 & 4 & 9 & 4 & 6 \\
\hline & 広島 & 2 & 1 & 2 & 1 & 1 & 4 & 3 & 7 & 7 & 10 & 8 & 6 \\
\hline & 山口 & 0 & 1 & 2 & 1 & 1 & 1 & 2 & 3 & 0 & 1 & 4 & 5 \\
\hline \multirow{4}{*}{ 高松 } & 徳皿 & 1 & 0 & 0 & 0 & 0 & 1 & 1 & 1 & 2 & 1 & 3 & 3 \\
\hline & 香川 & 1 & 0 & 0 & 1 & 0 & 0 & 0 & 2 & 2 & 0 & 1 & 2 \\
\hline & 愛媛 & 7 & 9 & 10 & 8 & 8 & 7 & 8 & 6 & 5 & 3 & 5 & 0 \\
\hline & 高知 & 6 & 6 & 7 & 4 & 4 & 4 & 5 & 9 & 11 & 9 & 7 & 5 \\
\hline \multirow{3}{*}{ 福岡 } & 福岡 & 19 & 19 & 21 & 19 & 24 & 25 & 27 & 28 & 37 & 48 & 34 & 32 \\
\hline & 佐賀 & 3 & 2 & 3 & 3 & 3 & 2 & 0 & 3 & 4 & 11 & 11 & 10 \\
\hline & 長崎 & 9 & 8 & 7 & 7 & 9 & 12 & 12 & 9 & 8 & 6 & 12 & 21 \\
\hline \multirow{4}{*}{ 熊本 } & 熊本 & 21 & 17 & 18 & 16 & 24 & 16 & 13 & 17 & 18 & 18 & 15 & 14 \\
\hline & 大分 & 19 & 15 & 16 & 20 & 21 & 13 & 17 & 20 & 23 & 24 & 23 & 28 \\
\hline & 宮崎 & 24 & 26 & 32 & 32 & 29 & 29 & 36 & 34 & 27 & 38 & 33 & 33 \\
\hline & 鹿罗曷 & 57 & 57 & 37 & 41 & 32 & 51 & 49 & 37 & 34 & 56 & 56 & 54 \\
\hline 沖䋲 & 沖縄 & 14 & 16 & 17 & 19 & 9 & 20 & 17 & 9 & 15 & 11 & 28 & 25 \\
\hline \multicolumn{2}{|c|}{ 出品都道府県数 } & 32 & 32 & 35 & 36 & 36 & 36 & 29 & 31 & 34 & 33 & 37 & 38 \\
\hline \multicolumn{2}{|c|}{ 出品点数合計 } & 244 & 248 & 245 & 247 & 249 & 268 & 247 & 253 & 280 & 335 & 337 & 347 \\
\hline
\end{tabular}

た低沸点香気成分（アセトアルデヒド，酢酸エチル， n-プロピルアルコール，イソブチルアルコール，酢 酸イソアミル及びイソアミルアルコール), ガスクロ マトグラフィー質量分析法 $(\mathrm{GC} / \mathrm{MS})$ を用いた中・
高沸点香気成分（カプロン酸エチル， $\beta$-フェネチル アルコール，酶酸 $\beta$ ーフェネチル，カプリル酸エチル， カプリン酸エチル，フルフラール及び高級脂肪酸エチ ルエステル（ラウリン酸エチル，ミリスチン酸エチ 
第 2 表 都道府県別出品場数の推移

\begin{tabular}{|c|c|c|c|c|c|c|c|c|c|c|c|c|c|}
\hline \multirow{3}{*}{ 国税局名 } & \multicolumn{12}{|c|}{ 出品場数 } & \\
\hline & 開催回数 & 19 & 20 & 21 & 22 & 23 & 24 & 25 & 26 & 27 & 28 & 29 & 30 \\
\hline & 開催年 & 1996 & 1997 & 1998 & 1999 & 2000 & 2001 & 2002 & 2003 & 2004 & 2005 & 2006 & 2007 \\
\hline 札幌 & 北海道 & 5 & 5 & 5 & 5 & 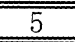 & 4 & 2 & 2 & 1 & 3 & 3 & $\overline{2}$ \\
\hline \multirow{6}{*}{ 仙台 } & 青森 & 0 & 1 & 1 & 1 & 1 & 1 & 0 & 0 & 0 & 0 & 0 & 1 \\
\hline & 岩手 & 0 & 0 & 1 & 4 & 4 & 3 & 2 & 1 & 0 & 0 & 0 & 3 \\
\hline & 宮城 & 0 & 0 & 0 & 0 & 0 & 0 & 0 & 0 & 0 & 0 & 0 & 1 \\
\hline & 秋田 & 3 & 2 & 2 & 2 & 3 & 2 & 1 & 2 & 2 & 2 & 1 & 2 \\
\hline & 山形 & 1 & 0 & 0 & 0 & 0 & 0 & 0 & 0 & 2 & 1 & 1 & 2 \\
\hline & 福富 & 2 & 3 & 2 & 2 & 4 & 4 & 1 & 0 & 1 & 0 & 1 & 3 \\
\hline \multirow{6}{*}{ 関東信越 } & 茨城 & 0 & 0 & 0 & 1 & 0 & 0 & 0 & 1 & 1 & 2 & 2 & 2 \\
\hline & 杤木 & 1 & 1 & 2 & 1 & 1 & 1 & 0 & 0 & 0 & 1 & 1 & 2 \\
\hline & 群馬 & 0 & 0 & 0 & 1 & 1 & 1 & 0 & 0 & 0 & 1 & 0 & 1 \\
\hline & 新潟 & 0 & 0 & 1 & 1 & 1 & 2 & 2 & 1 & 1 & 3 & 2 & 3 \\
\hline & 埼玉 & 0 & 0 & 0 & 0 & 1 & 0 & 0 & 0 & 0 & 2 & 0 & 0 \\
\hline & 長野 & 9 & 10 & 7 & 10 & 10 & 8 & 5 & 9 & 8 & 8 & 6 & 5 \\
\hline \multirow{4}{*}{ 東京 } & 千葉 & 4 & 2 & 1 & 1 & 1 & 3 & 1 & 1 & 2 & 2 & 1 & 2 \\
\hline & 山梨 & 1 & 0 & 1 & 1 & 1 & 1 & 1 & 1 & 1 & 0 & 0 & 0 \\
\hline & 東京 & 2 & 3 & 3 & 2 & 2 & 1 & 0 & 0 & 2 & 2 & 0 & 1 \\
\hline & 神奈川 & 1 & 0 & 1 & 1 & 0 & 0 & 0 & 0 & 1 & 0 & 0 & 0 \\
\hline \multirow{3}{*}{ 金沢 } & 石川I & 0 & 0 & 0 & 0 & 0 & 0 & 1 & 0 & 0 & 0 & 0 & 0 \\
\hline & 富山 & 1 & 1 & 1 & 1 & 1 & 1 & 0 & 0 & 0 & 1 & 1 & 0 \\
\hline & 福井 & 1 & 2 & 1 & 1 & 1 & 1 & 1 & 0 & 0 & 0 & 1 & 0 \\
\hline \multirow{4}{*}{ 名古屋 } & 岐阜 & 3 & 1 & 2 & 1 & 1 & 1 & 1 & 1 & 2 & 1 & 0 & 0 \\
\hline & 静岡 & 0 & 2 & 1 & 0 & 2 & 1 & 1 & 0 & 1 & 2 & 3 & 4 \\
\hline & 愛知 & 0 & 2 & 1 & 0 & 0 & 1 & 0 & 0 & 1 & 0 & 1 & 1 \\
\hline & 三重 & 0 & 0 & 0 & 0 & 0 & 0 & 0 & 0 & 0 & 0 & 1 & 2 \\
\hline \multirow{6}{*}{ 大阪 } & 泫賀 & 1 & 2 & 3 & 3 & 2 & 2 & 0 & 1 & 1 & 0 & 1 & 0 \\
\hline & 袁都 & 1 & 2 & 2 & 3 & 4 & 3 & 3 & 3 & 2 & 4 & 4 & 4 \\
\hline & 大阪 & 0 & 0 & 0 & 0 & 0 & 0 & 0 & 1 & 2 & 1 & 1 & 1 \\
\hline & 兵庫 & 3 & 4 & 5 & 5 & 3 & 1 & 3 & 3 & 4 & 3 & 3 & 5 \\
\hline & 奈良 & 2 & 2 & 2 & 3 & 4 & 2 & 1 & 1 & 0 & 0 & 1 & 1 \\
\hline & 和歌 1 & 0 & 1 & 1 & 1 & 1 & 2 & 0 & 0 & 0 & 1 & 1 & 3 \\
\hline \multirow{5}{*}{ 広島 } & 宜取 & 0 & 1 & 0 & 0 & 1 & 0 & 1 & 1 & 1 & 1 & 1 & 1 \\
\hline & 島根 & 2 & 0 & 0 & 0 & 0 & 0 & 0 & 1 & 2 & 0 & 1 & 2 \\
\hline & 岡山 & 1 & 3 & 2 & 1 & 5 & 3 & 4 & 3 & 2 & 3 & 2 & $\frac{w}{2}$ \\
\hline & 広島 & 2 & 1 & 2 & 1 & 1 & 3 & 2 & 3 & 3 & 5 & 3 & 3 \\
\hline & 山口 & 0 & 1 & 1 & 1 & 1 & 1 & 2 & 2 & 0 & 1 & 3 & 2 \\
\hline \multirow{4}{*}{ 高松 } & 德曷 & 1 & 0 & 0 & 0 & 0 & 1 & 1 & 1 & 2 & 1 & 2 & 2 \\
\hline & 香川 & 1 & 0 & 0 & 1 & 0 & 0 & 0 & 1 & 2 & 0 & 1 & 2 \\
\hline & 愛媛 & 4 & 5 & 5 & 4 & 4 & 2 & 4 & 2 & 2 & 2 & 3 & 0 \\
\hline & 高知 & 4 & 4 & 4 & 2 & 3 & 2 & 2 & 4 & 5 & 4 & 3 & 2 \\
\hline \multirow{3}{*}{ 福岡 } & 福㒺 & 10 & 11 & 8 & 7 & 9 & 9 & 8 & 8 & 11 & 12 & 7 & 10 \\
\hline & 佐賀 & 2 & 1 & 1 & 3 & 3 & 2 & 0 & 2 & 3 & 5 & 4 & 4 \\
\hline & 長崎 & 7 & 8 & 6 & 7 & 8 & 10 & 8 & 7 & 6 & 5 & 7 & 9 \\
\hline \multirow{4}{*}{ 熊本 } & 熊本 & 15 & 13 & 11 & 10 & 13 & 9 & 8 & 11 & 9 & 9 & 8 & 6 \\
\hline & 大分 & 14 & 11 & 12 & 12 & 13 & 10 & 10 & 8 & 10 & 10 & 8 & 10 \\
\hline & 宮崎 & 9 & 9 & 11 & 10 & 10 & 9 & 7 & 7 & 5 & 8 & 9 & 8 \\
\hline & 鹿罗亩 & 28 & 25 & 18 & 21 & 20 & 25 & 19 & 15 & 18 & 24 & 22 & 22 \\
\hline 沖縄 & 沖繶 & 9 & 9 & 11 & 9 & 5 & 11 & 10 & 5 & 8 & 6 & 14 & 12 \\
\hline \multicolumn{2}{|c|}{ 出品都道府県数 } & 32 & 32 & 35 & $\overline{36}$ & 36 & 36 & 29 & 31 & 34 & 33 & 37 & 38 \\
\hline \multicolumn{2}{|c|}{ 出品場数合計 } & 150 & 148 & 138 & 140 & 150 & 143 & 112 & 109 & 124 & 136 & 134 & 148 \\
\hline
\end{tabular}

ル，パルミチン酸エチル，リノール酸エチル，オレイ ン酸エチル及びステアリン酸エチルの定量値を合算し たもの）及びモノテルペンアルコール（甘譇焼酎のみ 分析, リナロール, $\alpha$-テルピネオール, シトロネロ
ール，ネロール及びグラニオール）の化学分析を行い ました。

ここ数年分析項目を増やしており，第 27 回より $\mathrm{GC} / \mathrm{MS}$ を用いた中・高沸点香気成分（前記，カプロ 
第 3 表 その他の原料の推移

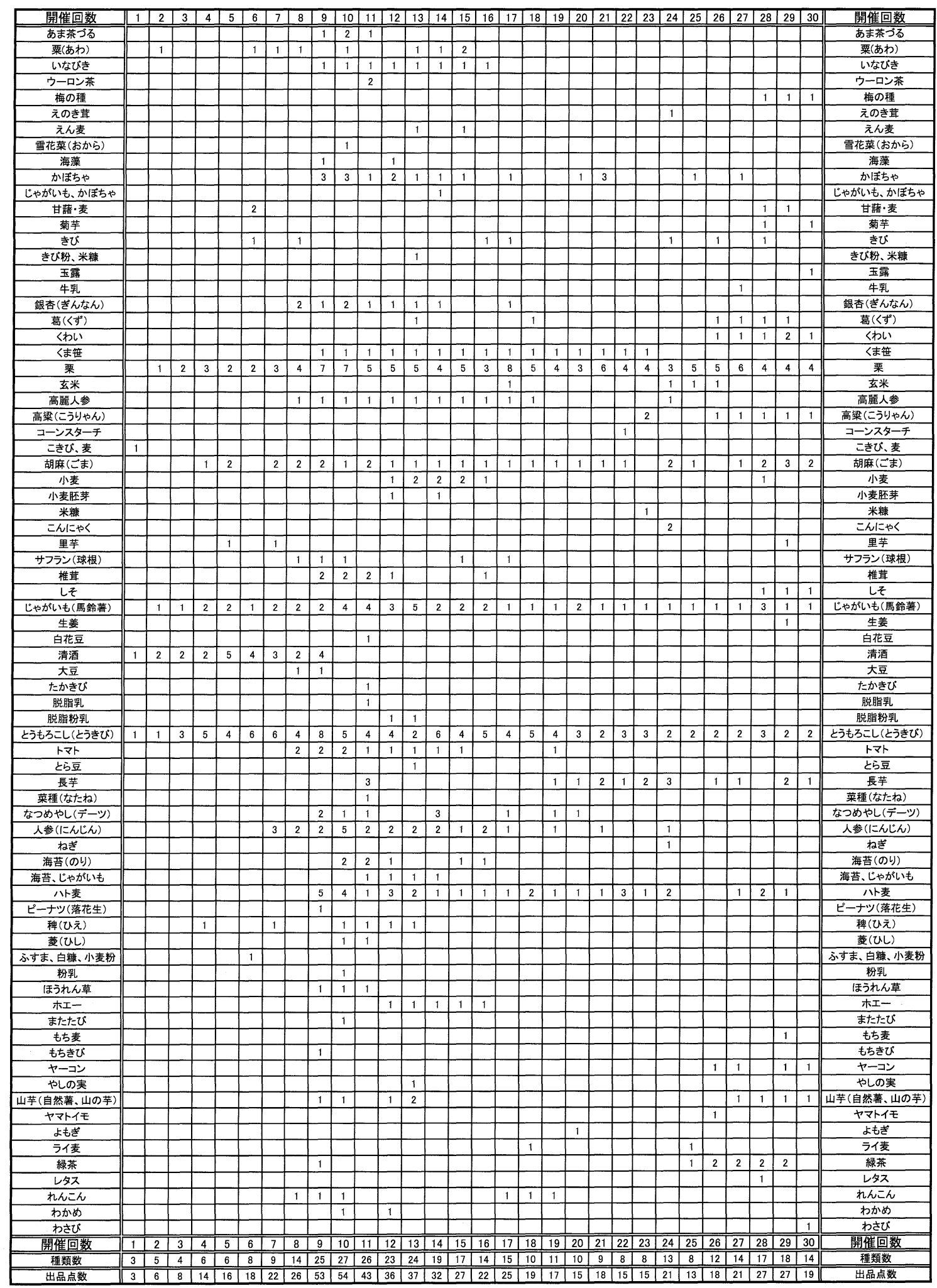

第 103 巻 第 1 号 


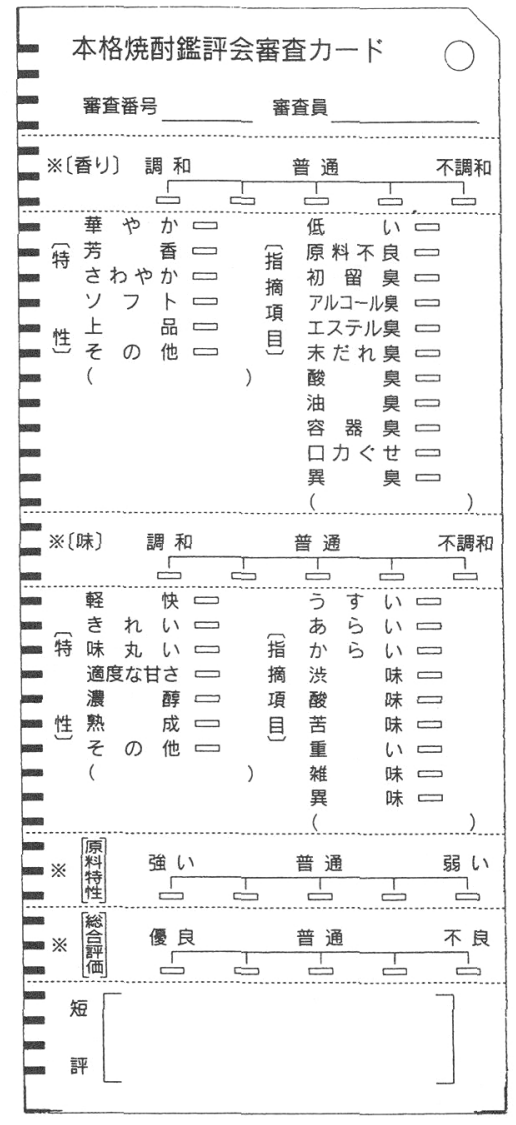

第 3 図官能審查カード

ン酸エチルからカプリン酸エチルまで）及び甘藷燒酎 の特徴香であるモノテルペンアルコールの分析を，第 28 回より GC によるアセトアルデヒド及び酢酸エチ ルの分析を，GC/MS を用いたフルフラール及び高級 脂肪酸エチルエステルの分析項目をそれぞれ追加しま した。

\section{5. 公開きき酒会について}

当研究所において，全出品酒を対象にした公開きき 酒会を開催しています。第 30 回目の本年は, 平成 19 年 6 月 29 日午前中に行われ，焼酎製造関係者を中心 に約 180 人の参加がありました(第 4 図)。な押，公 開きき酒会の終了後, 日本醸造協会主催の焼酎講演会 が昭和 60 年より開催されており，本格焼酎鑑評会の 出品状況や, 最新の焼酎研究成果等に関する講演が行 われています。



第 4 図きき酒会風景

\section{6. 麴菌の種類について}

焼酎用麴菌としては, 泡盛醸造を除くと, 戦後白麴 菌の使用が主流でしたが，近年甘藷焼酎を中心に黒麴 菌を使用した製品が増加しています。また，最近，製 品の特色を出すため, 黄䴯菌使用した甘藷焼㒋もみ られます。

出品酒の使用䴴菌についての調査は従来ほとんどあ りませんでした。そこで, 第 30 回出品酒の麴菌の種 類を米焼酎，麦焼酎，甘藷焼酎，及びそば焼酎につい て調べました(第 4 表)。米焼酎では, 白麴菌の使用 が 27 点, 黄麴菌の使用が 30 点と, 黄麳菌の使用割合 が他の原料に比べて高くなっていました。これは, 清 酒と米焼酎の両方を製造している製造場で，黄麴菌を 選択するケースが多いためです。麦焼酎では, 白麳菌 の使用が 72 点と大半を占めましたが, 黒䴯菌の使用 も 14 点みら机ました。甘藷焼酎では, 黒麴菌の使用 が 43 点であり白婙菌の 38 点よりも点数が多くなって いました。また, 黄楝菌の使用も6 点ありました。そ ば焼酎では, 白麳菌が 9 点で, 黄麳菌は 4 点使用され ていました。製品の特徴を出すため, 使用する麴菌の バラエティーが今後ますます広がっていくと考えられ ます。

麴菌の違いにより，化学成分值に違いがあるかを調 べるため，原料甘藷としてコガネセンガンを使用した 甘藷焼酎・常圧蒸留製品について, 使用麴菌（白麴 (21 点), 黒楝 (27 点)) 別に集計した結果を示しまし た(第 5 表)。神渡ら ${ }^{6}$ は, 甘藷焼酎について, 同一 会社製品の白麳製品と黒麳製品のモノラルペンアルコ ール（リナロール， $\alpha$-テルピネオール，シトロネロ 
第 4 表 棦菌の内訳(第 30 回本格焼酎鑑評会出品酒)

\begin{tabular}{|c|c|c|c|c|c|}
\hline & \multicolumn{4}{|c|}{ 第 30 回（2007 年） } \\
\hline & & 白䴹 & 黒麴 & 黄麴 & $\begin{array}{c}\text { その他・ } \\
\text { 不明 }\end{array}$ \\
\hline \multirow{4}{*}{ 米 } & 減圧蒸留 & 22 & 3 & 20 & 5 \\
\hline & 常圧蒸留 & 1 & 0 & 4 & 0 \\
\hline & 特殊製品 & 4 & 0 & 6 & 2 \\
\hline & 合計 & 27 & 3 & 30 & 7 \\
\hline \multirow{4}{*}{ 麦 } & 減圧蒸留 & 39 & 5 & 2 & 0 \\
\hline & 常圧蒸留 & 20 & 6 & 2 & 0 \\
\hline & 特殊製品 & 13 & 3 & 0 & 1 \\
\hline & 合計 & 72 & 14 & 4 & 1 \\
\hline \multirow{4}{*}{ 甘藷 } & 減圧蒸留 & 5 & 2 & 0 & 0 \\
\hline & 常圧蒸留 & 30 & 38 & 5 & 1 \\
\hline & 特殊製品 & 3 & 3 & 1 & 0 \\
\hline & 合計 & 38 & 43 & 6 & 1 \\
\hline \multirow{4}{*}{ そば } & 減圧蒸留 & 7 & 1 & 2 & 0 \\
\hline & 常圧蒸留 & 1 & 1 & 2 & 0 \\
\hline & 特殊製品 & 1 & 0 & 0 & 0 \\
\hline & 合計 & 9 & 2 & 4 & 0 \\
\hline
\end{tabular}

ール，ネロール及びゲラニオール）の合計值を比較す ると, 黒椈製品の方が高くなると報告しています。今 回，1つの会社から同じ銘柄で 2 種類（白麴又は黒麴 を使用している製品）の甘藷焼酎を出品している 5 社 について，モノテルペンアルコール量を比較しました が, 差はほとんどみられませんでした（第 5 表 (E))。

甘諸焼酎等の製造に黄麴菌を使用すると，白麴菌や 黒麴菌に比べ, 品質に与える影響が大きくなると考え られます。今回の結果から麴菌の違いによる品質の差 異について明確にすることはできませんでしたが, 麴 菌種の違いが本格焼酎の品質にどのような影響を与え るか興味がもたれます。

\section{7. 甘藷焼酎の最近の出品点数の増加の要因}

第 19 回以降における, 都道府県別の甘諸焼酎出品 点数の推移を第 6 表に示しました。従来, 甘藷焼酎の 出品は, 主産地である鹿児島県, 宮崎県等一部の県に 限られていました。しかし, 最近ではより多くの都府 県から出品されるようになっています。
ところで, 最近様々な甘藷品種で甘藷焼酎が製造さ れるようになってきましたが, 出品酒の使用甘藷品種 に関する調査は，これまでありませんでした。そこ で, 第 30 回出品甘藷焼酎の甘藷品種を調べました (第 7 表)。甘藷焼酎には従来からコガネセンガンが最 も多く使用されてきましたが, 今回もコガネセンガン は 59 点で, 全体の $2 / 3$ でした。他に, ベニアズマが 7 点, 鳴門金時が 5 点等計 27 点あり, 様々な品種で 甘藷焼酎が醸造されていることがわかりました。甘諸 焼酎の製造に適した甘藷品種の選抜が進められている ことや, 地元産の原料を利用した甘藷焼酎の醸造が全 国的に広がっているためと考えられます。

神渡ら ${ }^{7)}$ は, 甘藷焼酎の品質に及ぼす甘藷品種の影 響について調べ，紫系サツマイモを原料とした製品， 橙色系サッマイモを使用した製品, ジョイホワイトを 使用した製品では, 風味や特徵香成分が異なると報告 しています。原料甘藷の品種が品質に与える影響につ いて,さらなる解明が望まれます。

甘藷焼酎の出品点数の増加の要因は, 甘藷焼酎の課 税移出数量が伸びているという背景の他, 出品都府県 の増加, 甘藷使用品種の増加, 加えて, 使用する䴹菌 種の広がり等甘藷焼酎の多様化が進んだ結果と考えら れます。

\section{8. 酒質について}

出品酒の酒質の傾向について, 今回（第 30 回）の 審査講評を以下に記します。

（1）単式蒸留しょうちゅうの酒質は，近年飲み易 さを追求して淡麗で軽快なものが主流になっており, 今回の出品酒においてもその傾向が続いていた。麦製 の主力製品は, 品質が良くそろっており, きれいで欠 点のないマイルドなタイプが多かった。

今回も, 前回同様に泡盛の特殊製品の香り, 味及び 総合評価の平均点が何れも良好であり, 芳香, ソフ 卜，味丸い，濃醇という特性のものが多く見受けられ た。

（2）泡盛の特殊製品，酒粕製の常圧蒸留製品及び 泡盛の減圧蒸留製品では原料特性が高いという傾向が 認められた。また, 前回と同様に, 減圧蒸留製品と常 圧蒸留製品の酒質が近づきつつあるという傾向が見受 けられた。いずれの蒸留法においても, 品質の多様化 が進行しているものと思われる。 
第 5 表 䴹菌の違いによる甘諸焼酎成分の差異

(常圧蒸留製品かつ，コガネセンガンを使用した製品のみを集計に使用した。）

(A) 一般成分

\begin{tabular}{|c|c|c|c|c|c|c|}
\hline 麴 & 点数 & & $\mathrm{pH}$ & 酸度 & 紫外部吸収 & TBA 価 \\
\hline \multirow{2}{*}{ 白麴 } & \multirow{2}{*}{21} & 平均値 & 4.8 & 0.78 & 0.521 & 142 \\
\hline & & 標準偏差 & 1.0 & 0.45 & 0.194 & 50 \\
\hline \multirow{2}{*}{ 黒麴 } & \multirow{2}{*}{27} & 平均値 & 4.5 & 0.79 & 0.434 & 114 \\
\hline & & 標準偏差 & 0.7 & 0.47 & 0.156 & 57 \\
\hline
\end{tabular}

酸度, 紫外部吸収, TBA 価はアルコール分 $25 \%$ 換算

(B) 低沸点香気成分

\begin{tabular}{|c|c|c|c|c|c|c|c|c|}
\hline 麥米 & 点数 & & $\begin{array}{c}\text { アセトアル } \\
\text { デヒド }\end{array}$ & 酢酸エチル & $\begin{array}{c}\mathrm{n}-\text { プロパ } \\
\text { ノール }\end{array}$ & $\begin{array}{c}\text { イソブタノ } \\
\text { ール }\end{array}$ & $\begin{array}{c}\text { 酢酸イソア } \\
\text { ミル }\end{array}$ & $\begin{array}{l}\text { イソアミル } \\
\text { アルコール }\end{array}$ \\
\hline \multirow{2}{*}{ 白麴 } & \multirow{2}{*}{21} & 平均值 & 25.6 & 115 & 119 & 194 & 5.6 & 449 \\
\hline & & 標準偏差 & 8.3 & 41 & 27 & 24 & 2.4 & 73 \\
\hline \multirow{2}{*}{ 黒麴 } & \multirow{2}{*}{27} & 平均値 & 25.1 & 112 & 131 & 221 & 5.9 & 497 \\
\hline & & 標準偏差 & 8.9 & 29 & 33 & 47 & 2.1 & 85 \\
\hline
\end{tabular}

(単位：mg/1)，アルコール分 $25 \%$ 換算

(C) 中・高沸点香気成分

\begin{tabular}{|c|c|c|c|c|c|c|c|c|c|}
\hline 麴 & 点数 & & $\begin{array}{c}\text { カプロン酸 } \\
\text { エチル }\end{array}$ & $\begin{array}{c}\beta-フ ェ ネ \\
\text { チルアルコ } \\
\text { ール }\end{array}$ & $\begin{array}{c}\text { 酢酸 } \beta \text {-フ } \\
\text { エネチル }\end{array}$ & $\begin{array}{c}\text { カプリル酸 } \\
\text { エチル }\end{array}$ & $\begin{array}{c}\text { カプリン酸 } \\
\text { エチル }\end{array}$ & $\begin{array}{c}\text { フルフラー } \\
\text { ル }\end{array}$ & $\begin{array}{c}\text { 高級脂肪酸 } \\
\text { エチルエス } \\
\text { テル }\end{array}$ \\
\hline \multirow{2}{*}{ 白䴴 } & \multirow{2}{*}{21} & 平均値 & 0.2 & 46.4 & 1.7 & 1.8 & 2.5 & 2210 & 1799 \\
\hline & & 標準偏差 & 0.1 & 8.9 & 0.5 & 0.6 & 1.1 & 740 & 1717 \\
\hline \multirow{2}{*}{ 黒䴹 } & \multirow{2}{*}{27} & 平均値 & 0.2 & 52.1 & 1.9 & 1.6 & 2.5 & 1927 & 1313 \\
\hline & & 標準偏差 & 0.1 & 9.4 & 0.7 & 0.6 & 2.0 & 861 & 1374 \\
\hline
\end{tabular}

(単位：mg/l，ただし，フルフラールと高級脂肪酸エチルエステルは $\mu \mathrm{g} / 1$ )， アルコール分 $25 \%$ 換算

(D) モノテルペンアルコール

\begin{tabular}{|c|c|c|c|c|c|c|c|}
\hline 䴴 & 点数 & & リナロール & $\begin{array}{c}\alpha-\text { テ ピ } \\
\text { ネオール }\end{array}$ & $\begin{array}{c}\text { シトロネロ } \\
\text { ール }\end{array}$ & ネロール & $\begin{array}{c}\text { ゲラニオー } \\
\text { ル }\end{array}$ \\
\hline \multirow{2}{*}{ 白麴 } & \multirow{2}{*}{21} & 平均值 & 56.8 & 55.4 & 49.7 & 35.7 & 54.5 \\
\hline & & 標準偏差 & 12.0 & 17.1 & 22.9 & 16.3 & 16.6 \\
\hline \multirow{2}{*}{ 黒麴 } & \multirow{2}{*}{27} & 平均值 & 69.4 & 64.9 & 61.3 & 47.4 & 67.2 \\
\hline & & 標準偏差 & 30.2 & 37.4 & 29.3 & 22.2 & 27.1 \\
\hline
\end{tabular}

(単位: $\mu \mathrm{g} / 1), \quad$ アルコール分 $25 \%$ 換算

(E) モノテルペンアルコール

\begin{tabular}{|c|c|c|c|c|c|c|c|}
\hline 麴 & \multirow{2}{*}{ 点数 } & & リナロール & $\begin{array}{c}\alpha-\text { テルピ } \\
\text { ネオール }\end{array}$ & $\begin{array}{c}\text { シトロネロ } \\
\text { ール }\end{array}$ & ネロール & $\begin{array}{c}\text { ゲラニオー } \\
\text { ル }\end{array}$ \\
\hline \multirow{2}{*}{ 白麴 } & \multirow{2}{*}{5} & 平均值 & 59.5 & 58.5 & 50.5 & 36.9 & 55.3 \\
\cline { 3 - 8 } & & 標準偏差 & 8.8 & 16.3 & 33.0 & 19.0 & 15.1 \\
\hline \multirow{2}{*}{ 黒麴 } & \multirow{2}{*}{5} & 平均值 & 58.1 & 53.4 & 57.6 & 41.5 & 55.4 \\
\cline { 3 - 8 } & & 標準偏差 & 6.9 & 5.0 & 25.6 & 18.9 & 13.1 \\
\hline
\end{tabular}

(単位: $\mu \mathrm{g} / 1), \quad$ アルコール分 $25 \%$ 換算

（注）白䴹製品と黒麴製品の両方を出品していた 5 社にういて比較した。 
第 6 表 甘藷焼酎都道府県別出品点数の推移

\begin{tabular}{|c|c|c|c|c|c|c|c|c|c|c|c|c|c|}
\hline \multirow{2}{*}{ 国税局 } & 開催回数 & 19 & 20 & 21 & 22 & 23 & 24 & 25 & 26 & 27 & 28 & 29 & 30 \\
\hline & 開催年 & 1996 & 1997 & 1998 & 1999 & 2000 & 2001 & 2002 & 2003 & 2004 & 2005 & 2006 & 2007 \\
\hline 仙台 & 福島 & & & & & & & & & & & & 1 \\
\hline \multirow{3}{*}{ 関東信越 } & 茨城 & & & & & & & & & & 1 & 2 & 1 \\
\hline & 栃木 & & & & & & & & & & & 1 & 1 \\
\hline & 長野 & & & & & & & & & & 4 & 3 & 2 \\
\hline \multirow{2}{*}{ 東京 } & 千葉 & & & & & & & & & & & & 2 \\
\hline & 東京 & & & 1 & & & & & & 1 & 1 & & \\
\hline 名古屋 & 静岡 & & & & & & & & & 1 & 1 & 1 & 2 \\
\hline \multirow{2}{*}{ 大阪 } & 京都 & & & & & & & 2 & 2 & 2 & 2 & 2 & 2 \\
\hline & 大阪 & & & & & & & & 1 & 2 & 2 & 2 & 1 \\
\hline \multirow{4}{*}{ 広島 } & 鳥取 & & & & & & & 1 & 1 & 1 & 1 & 2 & 2 \\
\hline & 島根 & & & & & & & & & & & 3 & 1 \\
\hline & 広島 & & & & & & & & & 3 & 1 & 1 & 3 \\
\hline & 山口 & & & & & & & & & & 1 & 1 & 3 \\
\hline \multirow{2}{*}{ 高松 } & 徳島 & & & & & & & & & & 1 & 3 & 3 \\
\hline & 愛媛 & & & & & & & & & & & 1 & \\
\hline \multirow{3}{*}{ 福岡 } & 福岡 & & & & & & & & & 2 & & 1 & 3 \\
\hline & 佐賀 & & & & & & & & & & 1 & 1 & 2 \\
\hline & 長崎 & & 1 & & & & 1 & 1 & 1 & & & & \\
\hline \multirow{3}{*}{ 熊本 } & 熊本 & & & & & & & & & & 1 & 2 & 2 \\
\hline & 宮崎 & 5 & 3 & 6 & 5 & 7 & 6 & 10 & 10 & 7 & 12 & 12 & 16 \\
\hline & 鹿児島 & 23 & 20 & 15 & 19 & 20 & 27 & 29 & 22 & 26 & 40 & 41 & 41 \\
\hline 合計 & - & 28 & 24 & 22 & 24 & 27 & 34 & 43 & 37 & 45 & 69 & 79 & 88 \\
\hline
\end{tabular}

第 7 表 甘藷の品種の内訳（第 30 回出品酒）

\begin{tabular}{cc}
\hline 甘藷品種 & 出品点数 \\
\hline コガネセンガン & 59 \\
ベニアズマ & 7 \\
鳴門金時 & 5 \\
シロサツマ & 3 \\
金時 & 2 \\
高系 14 号 & 2 \\
ベニコトブキ & 2 \\
その他の品種 & $6(※)$ \\
不明・混合使用 & 2 \\
\hline 合 計 & 88 \\
\hline
\end{tabular}

※ その他の品種の内訳

(アヤムラサキ，開聞紫芋，九州 130 号，種子島 紫七号，ハマコマチ，ムラサキマサリ：各 1 点）

（3）長期貯蔵酒等の特殊製品は, 貯蔵管理技術の 進歩により，香味の調和のとれた高品質のものが多か った。泡盛の特殊製品において, その傾向が顕著に認
められた。

一方，麦製の樽貯蔵酒のように原料特性が失われた ものや, 減圧蒸留原酒の場合, 貯蔵年数にも拘わらず 香味の熟成が進んでいないものが散見された。

\section{9. おわりに}

酒類総合研究所で昭和 52 年より開催してきた本格 焼酎鑑評会は，平成 19 年で 30 回目を迎えました。こ の間, 単式蒸留しょうちゅうの製成数量は 5.8 倍に増 加し，広く全国的に消費されるようになりました。

本格燒酎は, もともと伝統性, 地域性の強い酒類で すが，伝統性や地域性を残しつつ，原料，産地，製 法, 酒質等の多様化が益々進んでいることがわかりま した。このことが消費者に受け入れられ，単式蒸留し ょうちゅうの製成数量の増加につながっているものと 思われます。

今後も本格燒酎の品質の向上や多様化のため, 本格 
焼酎鑑評会が果たす役割は大きいものと考えられま す。

おわりに，三上重明醸造技術基盤研究部門長，及び 家藤治幸醉造技術応用研究部門長には，本記事をまと めるにあたりご指導いただきました。また，韓錦順氏 には GC/MS 分析を行っていただきました。以上の 方々に深く感謝いたします。<(独)酒類総合研究所>

\section{文献}
1）中野成美：醸協，102，162-167（2007）
2）菅間誠之助：釀協，73，626-628（1978）
3）大場俊輝：䁔協，86，645-650（1991）
4）三上重明：醸協，97，849-862（2002）
5）菅間ら：醸試報，149，9-23（1977）
6）神渡 巧ら：酹協，98，729-736（2003）
7）神渡 巧ら：醸協，101，437-445（2006）

執筆者紹介（順不同・敬称略）

向井伸彦 $<$ Nobuhiko MuKaI $>$

昭和 43 年 2 月 18 日生まれ<勤務先とその所在地> 独立行政法人酒類総合研究所, T 739-0046 広島県東 広島市鏡山 3-7-1<略歴>平成 4 年東京工業大学大学 院理工学研究科修士課程修了, 同年 4 月国税庁入庁, 平成 5 年 4 月広島国税局課税第 2 部鑑定官室，平成 8 年 7 月国税庁醸造研究所（現酒類総合研究所）プロセ 又工学研究室, 以降環境保全研究室, 酒類理化学研究 室, 技術開発研究室を経て現在醸造技術応用研究部門 主任研究員。
小笠原靖 $<$ Yasushi OGASAWARA $>$

昭和 41 年 10 月 7 日生まれ<勤務先とその所在地> (株) ミツカン， ₹ 475-8585 愛知県半田市中村町 2-6 $<$ 略歴>平成 4 年東京大学大学院農学系研究科修士課 程修了, 平成 4 年 4 月 (株) 中埜酢店 (現 (株) ミツカン) 入社, 中央研究所・マーケティング本部等勤務, 現在 に至る。<抱負＞大ヒット商品の開発のお手伝いをし たい。く趣味＞ささやかなガーデニング。 